\title{
ROBOT PEMADAM API MENGGUNAKAN METODE FUZZY LOGIC
}

\author{
Febri Maspiyanti, Nadya Hadiyanti \\ Teknik Informatika Universitas Pancasila \\ febri.maspiyanti@univpancasila.ac.id, nadyahadiyanti96@gmail.com
}

\begin{abstract}
Fire Fighter Robot is a robot that can do one of the tasks that dangerous for human, namely firefighting duties. Most cases of fire encountered by the firefighters is a fire that happened in the building. In this research, we will build a prototype robot that acts as an emergency tool for firefighters inside the building using fuzzy logic method. This robot is built using ATmega328 microcontroller as the main control, Ultrasonic Sensor as distance detector between the robot and the obstacles, Flame Sensor to detect fire source, and L9110 Fan to extinguish fire. In this research, Fuzzy Logic is implemented in robot DC motor speed control with distance as the input. This study obtain $92,63 \%$ of average accuracy for move straight, $82,82 \%$ for turn, $81,59 \%$ of accuracy for distance reading by Ultrasonic Sensor, $87,25 \%$ of accuracy for fire detection with a Flame Sensor, and 52,11\% of accuracy rate to extinguish the fire with L9110 Fan Module.
\end{abstract}

Keywords : Fire Fighters Robot, Ultrasonic Sensor, Flame Sensor, Speed of DC Motor, Fuzzy Logic.

\begin{abstract}
ABSTRAK
Robot Pemadam Api adalah suatu jenis robot yang dapat melakukan salah satu tugas manusia yang berbahaya, yaitu tugas pemadam kebakaran. Sebagian kasus kebakaran yang dihadapi oleh pemadam kebakaran adalah kebakaran yang terjadi disebuah gedung. Pada penelitian ini akan membagun sebuah robot prototype yang berperan sebagai alat darurat pemadam kebakaran dalam gedung menggunakan metode Fuzzy Logic. Robot ini dibangun dengan menggunakan microcontroller ATmega328 sebagai kontrol utama, Sensor Ultrasonik sebagai pendeteksi jarak antara robot dengan halangan, Flame Sensor untuk menangkap pantulan cahaya api dari sumber apinya, and L9110 fan module sebagai alat pemadam api. Penerapan Fuzzy Logic pada robot ini adalah sebagai kendali kecepatan Motor DC robot dengan masukan jarak. Penelitian ini menghasilkan tingkat akurasi sebesar 92,63\% untuk berjalan lurus, jalan berbelok 82,82\%, pembacaan jarak oleh Sensor Ultrasonik 81,59\%, deteksi api dengan Flame Sensor 87,25\%, dan tingkat akurasi memadamkan api dengan L9110 Fan Module sebesar $52,11 \%$.
\end{abstract}

Kata kunci : Robot Pemadam Api, Sensor Ultrasonik, Flame Sensor, Kecepatan Motor DC, Fuzzy Logic.

\section{PENDAHULUAN}

\section{A. Latar Belakang}

Pada era globalisasi ini perkembangan ilmu pengetahuan dan teknologi semakin maju dan telah menghasilkan banyak peralatan yang diciptakan dengan maksud dapat memudahkan pekerjaan manusia, dapat dioperasikan secara manual ataupun otomatis, peralatan-peralatan otomatis tersebut juga telah berkembang dalam bentuk robot. Robot merupakan rangkaian perangkat keras (hardware) yang dilengkapi dengan perangkat lunak (software) berupa program penggerak, dan digunakan dalam pekerjaan tertentu, seperti kegiatan yang biasanya dilakukan di industri seperti mengantarkan barang/surat [6], pekerjaan yang membutuhkan ketelitian tinggi, membutuhkan tenaga yang besar, beresiko tinggi atau berbahaya, maupun pekerjaan yang berulang 
[4]. Salah satu pekerjaan manusia yang dapat dilakukan oleh robot adalah pemadam kebakaran, peranan manusia untuk memadamkan api pada suatu tempat yang sulit atau bahkan berbahaya dapat digantikan [1].

Robot pemadam api bergerak dibawah kendali board microcontroller Arduino UNO ATmega328, berfungsi sebagai otak yang bertanggungjawab atas pergerakan dan aktifitas yang dilakukan oleh robot. Perangkat microcontroller ini dihubungkan dengan perangkat motor driver untuk dapat mengendalikan kecepatan perputaran roda yang terhubung dengan motor DC pada robot. Dengan motor driver kecepatan perputaran roda dapat dikendalikan baik cepat maupun lambat [2].

Metode yang digunakan untuk implementasi logika dasar yang menggerakan robot untuk menghindari halangan adalah metode Fuzzy Logic. Pada logika klasik Boolean diyatakan bahwa segala hal dapat diekspresikan dalam istilah binary (0 atau 1, hitam atau putih, ya atau tidak), sementara itu Fuzzy Logic menggantikan kebenaran boolean dengan tingkat kebenaran, sehingga memungkinkan nilai keanggotaan antara 0 dan 1 [1]. Dalam implementasi robot pemadam api ini, metode Fuzzy Logic diterapkan pada bagian aktuator robot yang diatur oleh motor driver, yang bertujuan untuk mengatur kecepatan perputaran roda saat terdapat halangan atau tidaknya didepan robot, serta delay waktu yang perlukan apabila robot akan berbelok untuk mengindari halangan.

\section{LANDASAN TEORI}

\section{A. Robot Pemadam Api}

Robot Pemadam Api adalah Robot cerdas yang berjalan mencari target (titik api) pada suatu arena (track) yang mensimulasi ruangan dalam sebuah bangunan. Robot Pemadam Api dikendalikan oleh sebuah piranti kontrol yang telah diprogram untuk menyelesaikan misinya [4]. Robot Pemadam Api dapan membatu bahkan menggantikan peranan manusia untuk memadamkan api pada suatu daerah yang sulit atau bahkan berbahaya untuk dijangkau [1].

\section{B. Microcontoller}

Microcontroller merupakan otak dari sebuah Robot, berfungsi sebagai media penyimpanan data-data yang digunakan Robot, dalam hal ini data yang dimaksudkan adalah data tindakan Robot yang telah selesai diprogram sebelumnya.

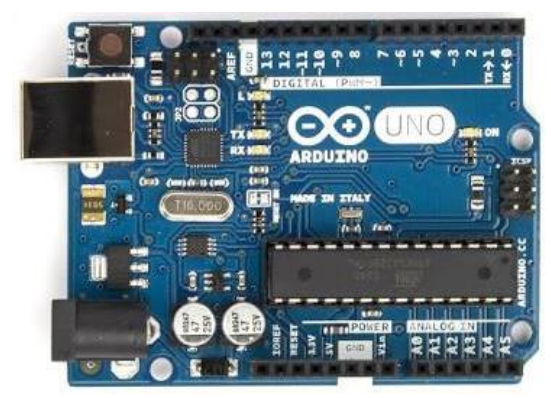
Gambar 2.1 Microcontroller Arduino Uno
ATMega328

Pada Gambar 2.1 merupakan gambaran sebuah controller Arduino Uno dengan tipe ATMega328. Arduino memiliki 14 pin input dan output yang terdiri dari 6 pin yang dapat digunakan sebagai output Pulse Width Modulation (PWM), 6 analog input, crystal osilator $16 \mathrm{MHz}$, koneksi Universal Serial Bus (USB), jack power, kepala In Circuit Serial Programming (ICSP), dan tombol reset.

\section{Sensor Ultrasonik}

Sensor Ultrasonik atau biasa disebut Sensor Jarak (Ping), di dalam penelitian ini sensor jarak digunakan untuk mendeteksi adanya hambatan (obstacle) yang menghalangi jalannya robot ketika sedang menelusuri arena dalam pencarian sumber api.

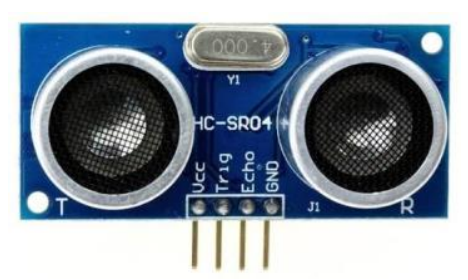

Gambar 2.2 Sensor Ultrasonik

\section{Sensor Api}

Dalam penelitian ini sensor api yang digunakan adalah jenis Flame Sensor 5Channel, digunakan untuk mendeteksi sumber 
api yang diletakkan di salah satu ruangan pada arena.

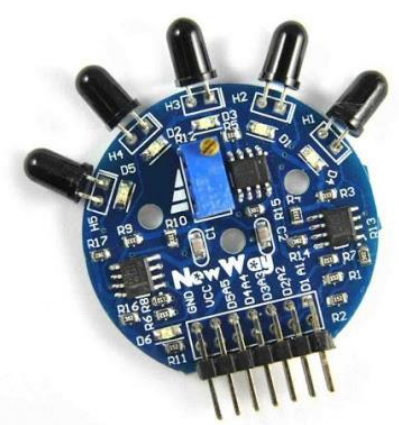

Gambar 2.3 Flame Sensor 5-Channel

Dapat dilihan Gambar 2.3 merupakan gambaran dari Flame Sensor 5-Channel. Sensor ini memiliki 5 sensor api, tiap sensor memiliki lampu indikator, dan sensor dapat mendeteksi api dengan range $120^{\circ}$. Mendeteksi api dengan range panjang gelombang $700-1100 \mathrm{~nm}$. Sensor akan berintegrasi dengan microcontroller Arduino yang merupakan otak atau tempat penyimpanan perintah deteksi api pada robot.

\section{E. Motor DC}

Motor DC pada Robot Pemadam Api adalah penggerak utama robot yang membuat robot dapat bergerak maju, mundur dan berbelok ke kiri atau ke kanan. Motor DC mengubah tegangan DC menjadi putaran dengan kecepatan sebanding dengan arus yang mengalir pada motor.

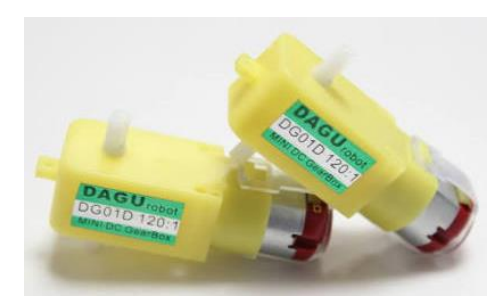

Gambar 2.4 Motor DC

Arus listrik yang mengalir pada kumparan di dalam motor DC terdapat dua kutub magnet permanen yang berlawanan (kutub utara dan selatan).

\section{F. Fuzzy Logic}

Fuzzy logic pertama kali dikembangkan oleh Prof. Lotfi A. Zadeh, seorang peneliti dari Universitas California, pada tahun 1960-an.
Fuzzy logic dikembangkan dari teori himpunan fuzzy [3]. Himpunan fuzzy adalah pengelompokan sesuatu berdasarkan variabel bahasa (linguistik variable), yang dinyatakan dengan fungsi keanggotaan, dalam semesta U. Keanggotaan suatu nilai pada himpunan dinyatakan dengan derajat keanggotaan yang nilainya antara 0.0 sampai 1.0 [3].

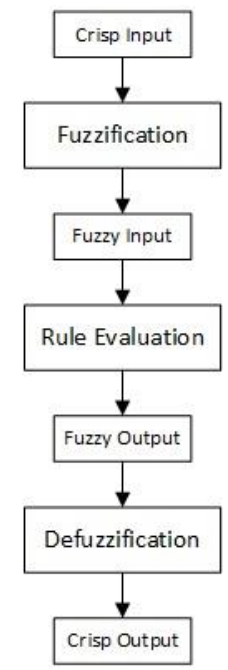

\section{Gambar 2.5 Proses Fuzzy Logic}

Pada Gambar 2.5 merupakan langkahlangkah yang dilakukan pada metode Fuzzy Logic.

1. Crisp input $\rightarrow$ input awal berupa jarak dengan satuan $\mathrm{cm}$, yang diperlukan untuk melakukan proses.

2. Fuzzification $\rightarrow$ proses untuk mengubah variabel non fuzzy (satuan $\mathrm{cm})$ menjadi variabel fuzzy.

3. Fuzzy input $\rightarrow$ nilai fuzzy yang merupakan hasil dari proses fuzzification.

4. Rule evaluation $\rightarrow$ proses evaluasi nilai yang dihasilkan terhadap rules yang telah ditentukan. Dalam penelitian ini melakukan evaluasi rules dengan operator dasar UNION, dengan penggunaan operator AND. Terjadi ketika salah satu maupun kedua elemen himpunan terpenuhi. Berikut ini merupakan rules yang berlaku pada perhitungan kecepatan motor robot digunakan pada penelitian ini:

1. Jika jarak sensor depan far, maka motor kiri fast dan motor kanan fast. 
2. Jika jarak sensor depan medium, maka motor kiri medium dan motor kanan medium.

3. Jika jarak sensor depan near, maka motor kiri slow dan motor kanan slow.

4. Jika jarak sensor depan near dan sensor kiri near, maka motor kiri medium dan motor kanan delay.

5. Jika jarak sensor depan near dan sensor kanan near, maka motor kiri delay dan motor kanan medium.

5. Fuzzy Output $\rightarrow$ variabel fuzzy yang merupakan hasil keluaran dari proses rules evaluation.

6. Defuzzification $\rightarrow$ proses pengubahan besaran fuzzy dalam bentuk himpunan fuzzy untuk mendapat kembali bentuk tegasnya (crisp). Pada penelitian ini metode yang digunakan pada perhitungan velocity Robot pada penelitian ini adalah metode weighted average, yakni sebuah metode yang mengambil nilai rata-rata dari ketetapan velocity dan waktu delay yang telah dibuat sebelumnya untuk permograman perintah Robot Pemadam Api. Rumus defuzzifikasi weighted average:

$$
Z^{*}=\frac{\sum_{i=0}^{n} W_{i} x Z_{i}}{\sum_{i=0}^{n} W_{i}}
$$

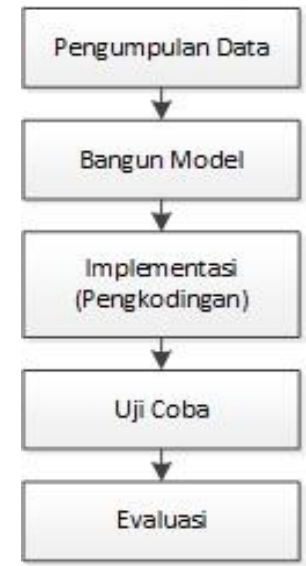

Gambar 3.1 Alur Penelitian

\section{A. Data}

Eksperimen ini menggunakan data hasil deteksi dari Sensor Ultrasonik dikonversikan kedalam satuan centimeter $(\mathrm{cm})$ sebagai jarak input yang akan diproses kedalam Fuzzy Logic, untuk menghasilkan output dalam bentuk kecepatan putaran motor DC robot.

\section{B. Perancangan Program Robot}

Sebelum melakukan pemrograman sebaiknya melakukan perancangan program, dengan menentukan logika yang akan dijalankan oleh robot. Berikut adalah langkahlangkah dari tindakan robot dari awal robot diaktifkan:

Keterangan:

$Z^{*}=$ Hasil defuzzifikasi

$\mathrm{Wi}=$ Bobot hasil fuzzifikasi

$\mathrm{Zi}=$ Nilai pada puncak himpunan anggota segitiga.

7. Crisp output $\rightarrow$ hasil keluaran proses defuzzification dalam bentuk nilai tegasnya.

\section{METODOLOGI}

Secara garis besar penelitan Robot ini memiliki tahapan pengerjaan seperti berikut: 


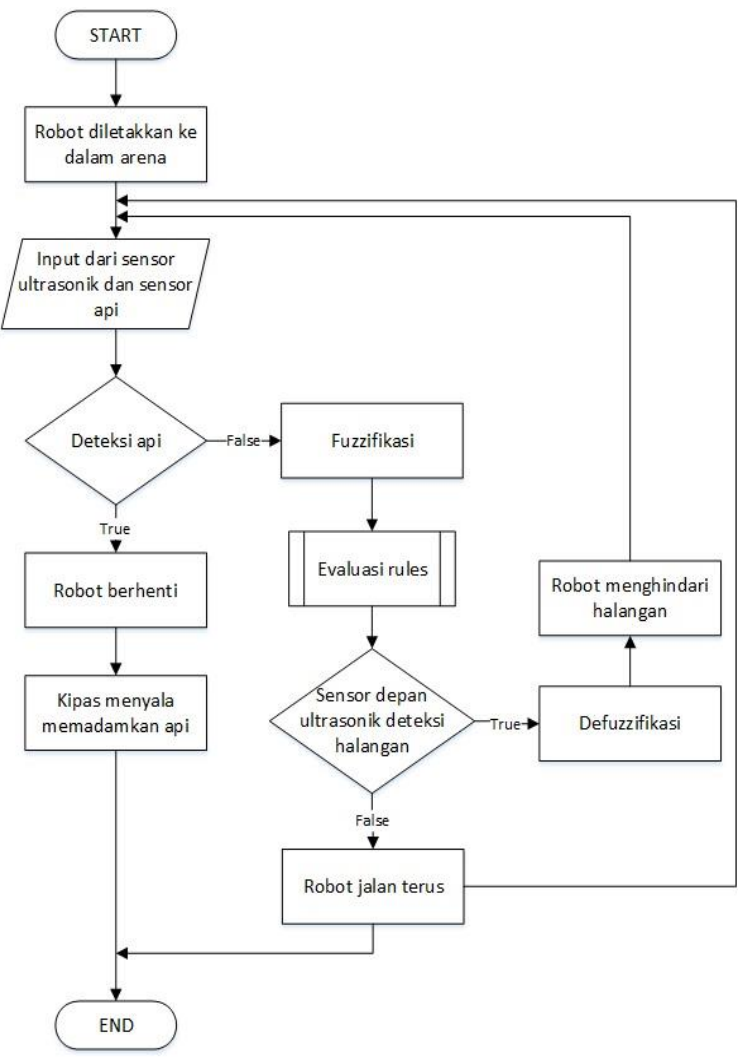

Gambar 3.2 Flowchart Program Robot

Pada Gambar 3.3 merupakan diagram alur dari program robot secara garis besar, yang menjadi tugas utama dan tindakan utama yang akan dilakukan oleh robot. Dimulai dari diletakkannya robot didalam arena yang menjadi track lintasan dari pencarian sumber api. Dalam penelitian ini Sensor Ultrasonik pada bagian depan menjadi default atau sensor utama yang menjadi navigasi pergerakan Robot Pemadam Api. Setelah mendapat input dari Sensor Ultrasonik maka akan dilakukan proses Fuzzy Logic untuk menghasilkan output yang diterapkan ke motor DC robot. Kemudian Robot Pemadam Api juga mendapat nilai input dari Flame Sensor, jika dalam perjalanan menelusuri arena terdeteksi sumber api pada jarak dekat, dan berada didepan robot makan Robot Pemadam Api akan berhenti. Setelah itu komponen kipas akan aktif dan mencoba untuk memadamkan sumber api.

\section{Metode Fuzzy Logic}

Dalam peneletian ini Fuzzy Logic akan diterapkan pada kecepatan motor (velocity) dan motor delay berdasarkan jarak antara robot dengan halangan yang ada saat menelusuri arena. Perhitungan ini maksudkan sebagai bahan pembuktian keluaran yang dihasilkan sesuai atau tidak sesuai dengan rules inferensi yang telah ditentukan.

- $\quad$ Input jarak depan $=32$, $\operatorname{kanan}=27$, kiri $=$ 32 , belakang $=26$

- Fuzzifikasi

\section{a. Sensor Depan}

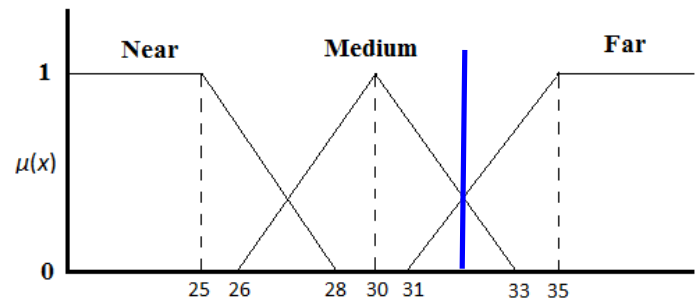

Gambar 3.3 Fuzzy Set Jarak Deteksi Sensor Depan

$$
\begin{aligned}
\mu(32)_{\text {medium }} & =(c-x) /(c-b) \\
& =(35-32) /(35-31) \\
& =3 / 4 \\
& =0.75 \\
\mu(32)_{\text {far }} & =(x-a) /(b-a) \\
& =(32-30) /(33-30) \\
& =2 / 3 \\
& =0.67
\end{aligned}
$$

b. Sensor Kanan

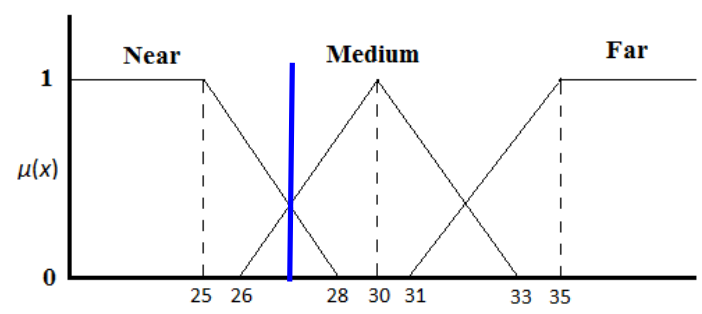

Gambar 3.4 Fuzzy Set Jarak Deteksi Sensor Kanan

$$
\begin{aligned}
\mu(27)_{\text {near }} & =(c-x) /(c-b) \\
& =(28-27) /(28-25) \\
& =1 / 3 \\
& =0.33 \\
\mu(27)_{\text {medium }} & =(x-a) /(b-a) \\
& =(27-26) /(30-26) \\
& =1 / 4 \\
& =0.25
\end{aligned}
$$


c. Sensor Kiri

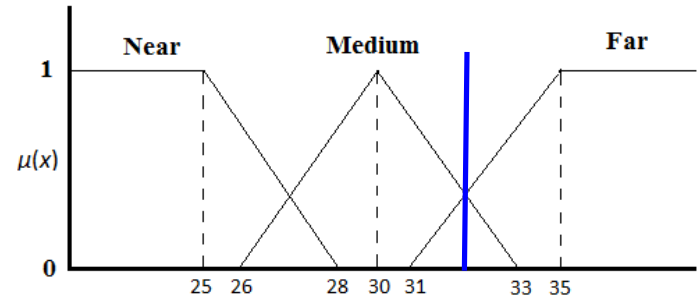

Gambar 3.5 Fuzzy Set Jarak Deteksi Sensor Kiri

$$
\begin{aligned}
\mu(32)_{\text {medium }} & =(c-x) /(c-b) \\
& =(35-32) /(35-31) \\
& =3 / 4 \\
& =0.75 \\
\mu(32)_{\text {far }} & =(x-a) /(b-a) \\
& =(32-30) /(33-30) \\
& =2 / 3 \\
& =0.67
\end{aligned}
$$

d. Sensor Belakang

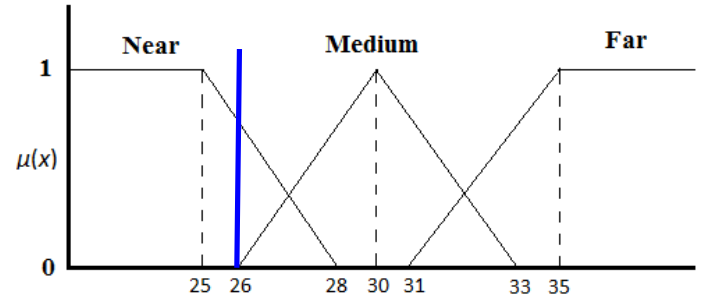

Gambar 3.6 Fuzzy Set Jarak Deteksi Sensor Belakang

Karena $\mathrm{x}=\mathrm{b}$ maka:

$\mu(26)_{\text {near }}=1$

Karena $\mathrm{x} \leq \mathrm{a}$ maka:

$\mu(26)_{\text {medium }}=0$

- Evaluasi rules dengan operator dasar UNION, dengan penggunaan operator AND:

$(\mathrm{R} 1) \rightarrow$ dua motor $\operatorname{fast}(\min (0.67)) \rightarrow$ fast $(0.67) \rightarrow$ TRUE

$(\mathrm{R} 2) \rightarrow$ dua motor medium $(\min (0.25)) \rightarrow$ medium $(0.25)$

$(\mathrm{R} 3) \rightarrow$ dua motor slow $(\min (-)) \rightarrow \operatorname{slow}(-)$

$(\mathrm{R} 4) \rightarrow$ kiri medium, kanan delay $(\min (-,-))$

$\rightarrow$ medium(-)

$(\mathrm{R} 5) \rightarrow$ kiri delay, kanan medium(min($, 0.25)) \rightarrow$ medium $(-)$
- $\quad$ Defuzzifikasi

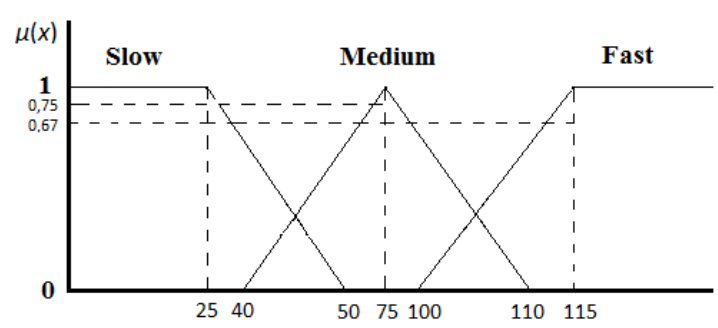

Gambar 3.7 Fuzzy Set Kecepatan Motor

Jika dihitung sesuai rumus, maka:

$$
Z *=\frac{(0,75 \times 75)+(0,67 \times 115)}{0,75+0,67}=93,87
$$

Dikarenakan hasil dari evaluasi rules yang terpenuhi adalah rule tanpa adanya delay, maka delay tidak digunakan. Berikut adalah grafik untuk waktu delay yang digunakan Robot ketika melakukan gerakan berbelok:

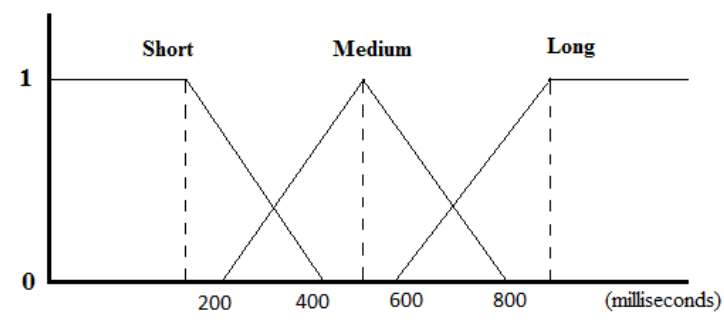

Gambar 3.8 Fuzzy Set Waktu Delay

\section{Perancangan Arena Robot}

Dalam penelitian ini telah ditentukan bahwa arena yang akan dilalui robot merupakan sebuah bangunan yang memiliki satu lantai yang terbagi menjadi 4 ruangan. Setiap ruangan memiliki ukuran luas dan keliling yang sama.

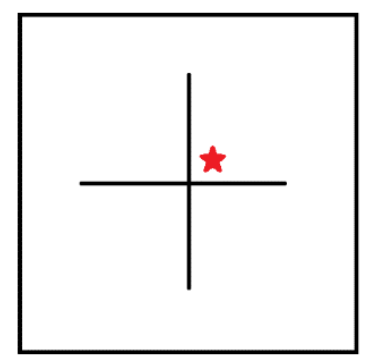

Gambar 3.2 Denah Arena Robot 
Gambar 3.2 merupakan gambaran sederhana dari denah yang menjadi arena robot untuk melakukan pencarian dan pemadaman sumber api. Garis atau area yang berwarna hitam merupakan sebuah dinding atau penghalang yang harus dihindari oleh robot. Kemudian untuk area yang ditandai dengan warna putih merupakan ruang yang dapat dilalui oleh Robot Pemadam Api dalam melakukan pencarian sumber api. Kemudian tanda bintang merah merupakan salah satu contoh tempat peletakan sumber api, yang dalam penelitian ini berupa lilin dengan tinggi $15-20 \mathrm{~cm}$. Posisi lilin akan selalu berpindah untuk setiap percobaan

Denah tersebut diwujudkan dengan menggunakan bahan dasar kardus sebagai dinding. Ukuran panjang setiap sisi kardus tersebut adalah 1,5 meter, karena bangunan tersebut memiliki bentuk persegi maka memiliki luas dan keliling:

$$
L=\operatorname{sisi} x \text { sisi }
$$

Keterangan:

$$
\begin{array}{ll}
\mathrm{L} & =\text { Luas persegi } \\
\text { Sisi } & =\text { Panjang sisi } \\
\mathrm{L} \quad & =1,5 \mathrm{~m} \times 1,5 \mathrm{~m} \\
& =2,25 \mathrm{~m}^{2} \\
\text { Kel } & =4 x \mathrm{sisi}
\end{array}
$$

Keterangan:

$$
\begin{aligned}
\text { Kel } & =\text { Keliling persegi } \\
\text { Sisi } & =\text { Panjang sisi } \\
\text { Kel } & =4 \times 1,5 \mathrm{~m} \\
& =6 \mathrm{~m}
\end{aligned}
$$

Kemudian untuk menentukan ukuran panjang sisi ruangan dapat dilihat pada rumus berikut:

$$
\text { PS ruang }=\frac{P S \text { persegi }}{2}
$$

Keterangan:

PS ruang $=$ Panjang sisi ruangan PS persegi $=$ Panjang sisi persegi

$$
\begin{aligned}
\text { PS ruang } & =\frac{1,5 \mathrm{~m}}{2} \\
& =0,75 \mathrm{~m}
\end{aligned}
$$

$$
\begin{aligned}
\mathrm{L} \text { ruang } & =0,75 \mathrm{~m} \times 0,75 \mathrm{~m} \\
& =0,05625 \mathrm{~m}^{2}
\end{aligned}
$$

Kel ruang $=4 \times 0,75 \mathrm{~m}$

$$
=3 \mathrm{~m}
$$

\section{E. Bangun Model}

Dalam menentukan komponen-komponen yang digunakan pada Robot Pemadam Api dapat berdasarkan fitur-fitur yang merupakan tugas dari robot ini:

1. Fitur Pendeteksi Api, fitur ini mempunyai tugas utama untuk memadamkan api dan untuk menyelesaikan tugasnya dibutuhkan fitur pendeteksi api.

2. Fitur Pendeteksi Jarak Robot Dengan Halangan, sama halnya dengan pendeteksi halangan (obstacle), fitur ini dibutuhkan oleh Robot Pemadam Api karena robot dapat menghindar saat menemui adanya halangan dihadapan Robot Pemadam Api saat robot sedang melakukan proses pencarian sumber api.

3. Fitur Penyimpanan Perintah, fitur yang berfungsi sebagai otak dari sebuah robot, salah atunya adalah sebuah microcontroller. Pada penelitain ini robot menggunakan sebuah microcontroller Arduino Uno ATMega328.

4. Fitur Berjalan, pada penelitian ini akan menggunakan komponen motor DC sebagai penggerak roda pada robot.

5. Fitur Pemadam Api, merupakan fitur yang bertugas untuk memadam api setelah menemukan target api. Pada penelitian ini menggunakan komponen L9110 Fan Module Arduino Uno sebagai fitur pemadam api.

\section{F. Akurasi}

Cara mendapatkan nilai untuk teknik evaluasi hasil dengan mengamati pergerakan atau perpindahan dalam menulusuri ruang-ruang tanpa menabrak dinding yang akan digunakan untuk simulasi, dan memadamkan sumber api yang nantinya akan dilakukan oleh robot. Perhitungan didapat dengan melakukan pembagian antara jumlah percobaan yang dilakukan dengan jumlah robot tersebut 
melakukan tugasnya dengan benar, kemudian dikalikan dengan presentase maksimal yaitu $100 \%$ untuk mengetahui tingkat akurasi yang dihasilkan oleh robot, dari penjelasan diatas maka rumus menghitung akurasi robot sebagai berikut:

$$
\text { Akurasi }=\sum \frac{A}{B} \times 100 \%
$$

Keterangan:

$\mathrm{A}=$ Jumlah robot melakukan tugas dengan benar

$\mathrm{B}=$ Jumlah uji coba yang dilakukan

\section{HASIL}

\section{A. Hasil Robot}

Hasil robot merupakan hasil dari komponen-komponen yang telah dirangkai menjadi satu kesatuan robot pemadam api yang utuh.

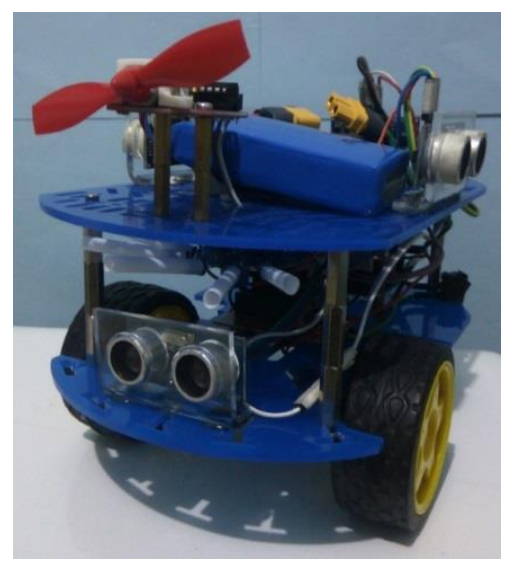

Gambar 4.1 Tampilan Robot Pemadam Api

Pada Gambar 4.1 merupakan tampilan Robot Pemadam Api yang telah selesai dirangkai. Bahasa pemrograman yang digunakan untuk membuat perintah robot ini adalah $\mathrm{C} / \mathrm{C}++$, salah satu faktor memilih menggunkan bahasa pemrograman tersebut pada penelitian ini adalah karena tesk editor Arduino Uno hanya support pada bahasa pemrograman $\mathrm{C} / \mathrm{C}++$.

\section{B. Hasil Eksperimen}

Pada penelitian ini, Robot Pemadam Api telah diuji setidaknya 163 kali percobaan diluar maupun di dalam arena yang menjadi jalur pencarian sumber api yang telah disediakan.
Terdapat beberapa aspek yang perhatikan dalan penelitian ini, yaitu:

1. Berjalan Lurus;

2. Berjalan Belok;

3. Mendeteksi Api;

4. Menghindari Obstacle Dengan Sensor Ultrasonik;

5. Memadamkan Api.

Uji coba dilakukan selama beberapa hari, pada setiap kali uji coba dilakukan \pm 30 kali percobaan. Berikut merupakan sample dari hasil uji coba yang dilakukan didalam arena:

Table 4.1 Hasil Uji Coba Arena

\begin{tabular}{|c|c|c|c|c|}
\hline No & Arena & $\begin{array}{c}\text { Deteksi } \\
\text { Api }\end{array}$ & Obstacle & $\begin{array}{c}\text { Deteks } \\
\text { Lilin }\end{array}$ \\
\hline 1 & $++_{x}$ & Sukses & 80 & Sukses \\
\hline 2 & $+{ }_{x}$ & Sukses & 60 & Gagal \\
\hline 3 & $\leftarrow^{x}$ & Sukses & 80 & Gagal \\
\hline 4 & $+_{x}$ & Sukses & 90 & Gagal \\
\hline 5 & + & Sukses & 60 & Sukses \\
\hline 6 & $+{ }_{x}$ & Sukses & 70 & Gagal \\
\hline 7 & + & Sukses & 80 & Gagal \\
\hline 8 &.$+t_{x}$ & Sukses & 60 & Sukses \\
\hline 9 & $\cdot \mathbf{c}^{\mathrm{x}} \mathrm{t}^{\mathrm{x}}$ & Sukses & 90 & Sukses \\
\hline 10 & + & Sukses & 70 & Sukses \\
\hline 11 & $+\cdot$ & Sukses & 80 & Sukses \\
\hline 12 & + & Sukses & 70 & Sukses \\
\hline
\end{tabular}




\begin{tabular}{|c|c|c|c|c|c|c|c|c|c|}
\hline 13 & $\dot{+}_{x}$ & Sukses & 80 & Sukses & 31 & $+^{x}$ & Sukses & 60 & Gagal \\
\hline 14 & $+_{x}^{\circ}$ & Sukses & 60 & Gagal & 32 & + & Sukses & 80 & Sukses \\
\hline 15 & $十_{x}$ & Sukses & 70 & Gagal & 33 & $+\dot{+}_{x}$ & Sukses & 80 & Sukses \\
\hline 16 & $\cdot+_{x}$ & Sukses & 70 & Sukses & 34 & $++_{x}$ & Sukses & 90 & Sukses \\
\hline 17 & $+_{x}$ & Sukses & 80 & Gagal & 35 & $+_{x}$ & Sukses & 80 & Gagal \\
\hline 18 & ${ }^{+}{ }_{x}$ & Sukses & 80 & Gagal & 36 & 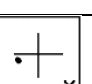 & Sukses & 80 & Sukses \\
\hline 19 & $+_{x}$ & Sukses & 70 & Sukses & 37 & ${ }^{*}+{ }_{x}$ & Sukses & 80 & Sukses \\
\hline 20 & $t_{x}$ & Sukses & 80 & Sukses & 38 & $\bar{x}+$ & Sukses & 70 & Gagal \\
\hline 21 & $t_{x}$ & Sukses & 90 & Gagal & 39 & $+{ }_{x}$ & Sukses & 90 & Sukses \\
\hline 22 & $+_{x}$ & Sukses & 70 & Sukses & 40 & $\cdot 十_{x}$ & Sukses & 80 & Sukses \\
\hline 23 & $+_{x}$ & Sukses & 80 & Sukses & 41 & ${ }^{+}+$ & Sukses & 80 & Gagal \\
\hline 24 & $+\cdot$ & Sukses & 60 & Gagal & 42 & $\leftarrow^{x}$ & Sukses & 90 & Sukses \\
\hline
\end{tabular}

Pada Tabel 4.1 dapat dilihat pada setiap percobaan posisi lilin yang ditandai dengan tanda titik selalu berpindah, dan posisi Robot Pemadam Api yang ditandai dengan tanda $\mathrm{x}$ disesuaikan. Untuk aspek menghindari obstacle diberikan nilai dengan range 10-100.

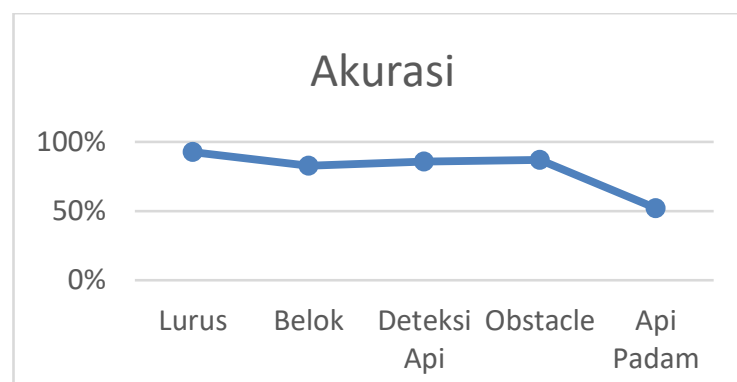

Gambar 4.2 Grafik Hasil Akurasi 
Pada Gambar 4.2 dapat dilihat hasil akurasi setelah pengujian dan perhitungan sebanyak 163 kali percobaan robot didapatkanlah hasil akurasi dengan beberapa aspek. Pada saat berjalan lurus dan berbelok, robot memiliki nilai akurasi yang tinggi, begitu juga dengan aspek lainnya. Namun hanya satu aspek yang memiliki akurasi 50\%, yaitu memadamkan api.

\section{KESIMPULAN}

\section{A. Kesimpulan}

Kesimpulan yang dapat ditarik dari penelitian pembuatan Robot Pemadam Api menggunakan metode Fuzzy Logic adalah penerapan Fuzzy Logic pada Sensor Ultrasonik telah bekerja dengan baik, dikarenakan dengan menggunakan tiga fuzzy set, yaitu near, medium dan far dan menghasilkan nilai dari tetapan Fuzzy Logic yang membuat pergerakan robot menjadi lebih baik karena disesuaikan dengan jarak robot dengan obstacle didepannya. Berdasarkan beberapa aspek yang ditentukan sesuai komponen yang digunakan didapatkanlah akurasi pada Robot Pemadam Api ini yaitu, mulai dari berjalan lurus menghasilkan tingkat akurasi sebesar 92,63\%, jalan berbelok memiliki tingkat akurasi $82,82 \%$, menghindari obstacle oleh Sensor Ultrasonik memiliki tingkat akurasi $81,59 \%$, mendeteksi api dengan Flame Sensor bernilai $87,25 \%$, dan tingkat akurasi memadamkan api dengan L9110 Fan Module, yaitu sebesar 52,11\%.

\section{B. Saran}

Saran yang dapat diberikan berdasarkan hasil penelitian ini adalah:

1. Perlu adanya penambahan fitur menghindari obstacle, dengan menambahkan jumlah Sensor Ultrasonik sebagai pembaca jarak, agar akurasi robot saat berjalan pada arena yang terdapat halangannya meningkat dan dapat dimaksimalkan dengan metode Fuzzy Logic.

2. Jika melakukan penambahan Sensor pada Robot Pemadam Api ini, Microcontroller harus digantikan, agar memiliki kapasitas dan jumlah pin untuk komponen yang lebih besar.

3. Perlu adanya penggantian alat untuk memadamkan api menjadi sebuah pompa air, agar dapat meningkatkan akurasi pada aspek pemadaman api.

\section{DAFTAR PUSTAKA}

[1] Azhar, Ari, Diah K.W., Kartina., Subagiyo, Heri. Perancangan Fuzzy Logic Model Sugeno untuk Wall Tracking pada Robot Pemadam Api. Jurnal ELEMENTER, Vol. 1, No. 1. 2015.

[2] Noviyantono, Endyk., Muhammad. Implementasi Logika Fuzzy Sebagai Pengendali Pergerakan pada Robot Beroda. STMIK PPKIA Tarakanita Rahmawati. Tarakan.

[3] Saelan, Athia. Logika Fuzzy. STEI ITB. Bandung. 2013.

[4] Widiyatmoko, Ari., Arifin, Fatchul. Robot Beroda Pemadam Api Dengan Pengolahan Sensor Api Berbasis Fuzzy Logic. Prosiding Seminar Nasional Elinvo, Vol.2. 2016.

[5] Winarno., Arifianto, Deni. Bikin Robot Itu Gampang. Kawan Pustaka. Jakarta. 2011.

[6] Putri, Andini., Maspiyanti. Robot Line Follower Pengantar Surat Menggunakan Metode Fuzzy Logic Studi Kasus Fakultas Teknik Universitas Pancasila. Jurnal Teknoogi Terpadu STT-NF. Vol.3, No.1. 2017. 